\title{
Market Definition in the Merger Guidelines: Implications for Antitrust Enforcement
}

\author{
Robert G. Harris $\dagger$ \\ Thomas M. Jorde
}

Antitrust lawyers and scholars have become increasingly cognizant of the importance of market definition to the development and implementation of antitrust law. Despite its importance, however, market definition remains highly problematic.

It is easy to see why. In a typical antitrust suit, the plaimtiff's experts will seek to minimize the geographic area of and the number of products in the market, so that the defendant will be viewed as occupying a large share of a small market. The defendant's experts will seek to do exactly the opposite. The result is that "[d]epending on who convinces the judge, the concentration ratios will be awesome or trivial, with a large influence on his verdict." "This has led the latest Nobel Laureate, Professor Stigler, to call the typical antitrust case "an almost impudent exercise in economic gerrymandering."

One might expect that an area which is so subject to inanipulation, but that can have such an impact on antitrust enforcement, would have received great attention froin lawyers and economists. This has not happened, however. As Stigler has noted, "Except for a casual flirtation with cross elasticities of demand and supply, the determination of markets has remamed an undeveloped area of economic research at either the theoretical or empirical level."3 Nevertheless, the Justice Department's approach to market definition set forth in the new Merger Guidelines merely adheres to neoclassical theory.

We believe that this approach is flawed for three main reasons. First, neoclassical theory, with its primary emphasis on economic effi-

$\dagger$ Professor of Business Administration, University of California, Berkeley. B.A. 1965, M.A. 1973, Michigan State University; Ph.D. 1977, University of California, Berkeley.

$\ddagger$ Professor of Law, Boalt Hall School of Law, University of California, Berkeley. B.A. 1969, J.D. 1972, Yale University.

1. Stigler, The Economists and the Problem of Monopoly, 72 AM. Econ. A. Proc., May 1982, at 1, 9 (Richard T. Ely Lecture, presented to the 94th Annual Meeting of the Ainerican Economic Association).

2. $1 d$. at 8.

3. Id. at 9 . 
ciency and its simplifying assumptions, is an insufficient basis for realworld antitrust policy and analysis. Second, the Guidelines use hypothetical firms and managers as part of their market definition process, which is imconsistent with commercial reality. Third, the Guidelines define markets in an overly broad manner, and are biased in the direction of constantly expanding markets.

Part I of this Article presents some general comments on the Guidelines and their implication that the Justice Department is now adhcring to neoclassical economic theory as the exclusive basis for antitrust policy and analysis. Part II outlines the market definition procedures contained in the Guidelines. Part III criticizes these procedures, on the general grounds described above. Part IV discusses the implications of the Departinent's market definition procedures for merger policy and for antitrust enforcement. Fimally, Part V presents an overview of a fundamentally diffcrent approach to market definition, which we beheve is more consonant with legislative intent and judicial interpretation of the antitrust laws. ${ }^{4}$

\section{Neoclassical Theory and Antitrust Policy}

It is our view that neoclassical price theory simply does not provide a sufficient basis on which to conduct antitrust policy. To be sure, price theory, even in its extreme versions, has many valuable uses. But the single-minded Chicago School emphasis on economic efficiency, as refiected in the Merger Guidelines, ignores other objectives of antitrust policy that had been considered important between 1890 and 1982. Furthernore, there is great danger when analysts or policymakers confuse the consequences assumed to flow from a simplified theoretical model with the realities of a complex economy.

\section{A. Economic Efficiency as an Antitrust Policy Objective}

Much has been said of late regarding the importance of economic efficicncy in public policy analysis. Nowhere has this been more true than in recent debates over government regulation of economic activity. While it is true that economic efficiency effects ought to be considered in the making and implementing of public policy, the thrust of the Merger Guidelines is that economic efficiency is the only factor relevant to the enforcement of antitrust laws. ${ }^{5}$

4. A full treatment of this approach can be found in R. Harris \& T. Jorde, Antitrust Market Definition (1983) (unpublished manuscript) (forthcoming in 71 CALIF. L. REv.).

5. Assistant Attorney General Baxter has stated that "[t]he statutes talk in terms of competition and restraints on trade-which I take to mean restraints on output and therefore a reference to the economists' concept of efficiency-and that's a challenging undertaking in itself. I feel no 
This view of the objectives of antitrust laws is grossly at odds with the legislative intent and content of those laws, and with their interpretation by the courts. Efficiency as a policy objective relates only to ensuring the best possible use of factors or outputs of production. Not only are other policy objectives important, but they often take precedence over efficiency considerations. The inost important of these other objectives are ensuring fairness in economic distribution ("equity") and fairness in the process of exchange ("procedural fairness"). 6

Equity concerns the distribution of wealth, incoine, goods, and services among individuals, households, and firms. A democratic society holds certain values about what constitutes a fair distribution of income. These values include the notion that income should be distributed to an individual in exchange for his providing socially valuable goods and services, rather than as a result of his exploitmg a market failure or of his illegal activities. ${ }^{7}$

There is a wide consensus that the antitrust laws were enacted in part to address these equity concerns. This consensus has been summarized by Scherer, who stated that even though Congress recognized that consumers were harmed when inonopolies increased prices by restraining output, one could not thereby conclude that Congress was concerned with economic efficiency. "To be sure," Scherer wrote, "Congress took exception to monopoly output restriction, elevated prices, and bloated profits, but it . . . was concerned at least as much with income distribution effects (which were well understood in 1890) as with efficiency effects (which were not)."8

Democratic societies also seek to maximize the procedural fairness

compulsion to expand it." Today's Policies on Antitrust, San Francisco Chron., Dec. 15, 1982, at A-6, col. 1, at A-8, col. 1 (interview with William F. Baxter, Jr.).

6. Professor Baumol has recently written, "Persons who design public policy are, typically, at least as concerned with issues of equity as with allocative efficiency. The economist's influence is therefore impeded by his inability to deal with issues of fairness in applied problems." Baumol, Applied Fairness Theory and Rationing Policy, 72 AM. Econ. Rev. 639, 639 (1982).

Like inost economists, however, Baumol equates procedural fairness with equity. Thus, he is concerned only with outcomes, not with the process through which they occur. Yet the most fundamental values in a democratic society-e.g., voting, free speeelı and assembly, and due process of law-are related to process and uot to outcome. Similarly, the philosophical argument for the market system of economic organization is that it provides for procedural fairness in cconounic transactions because in the purely competitive case, both parties to an exchangc have equal bargaining positions. That premise is violated wheu either party has market power.

7. See also R. Hofstadter, THE Age of Reform 221 (1955):

[People of the late 19th centuryl had been brought up to think of the well-being of society not inerely in structural terms-not as something resting upon the sun of its techrique and efficiency-but in moral terms, as a reward for the suin total of individual qualities and personal merits. This tradition . . . was being wantonly defled by the system of corporate organization.

8. Scherer, Book Review, 86 YALE L.J. 974, $977-79$ (1977) (reviewing R. Posner, ANTItrust LaW: AN ECONOMIC PERSPECTIVe (1976)). 
of economic transactions. It is no exaggeration to argue that the very philosophical premise of a capitalist market economy is a theory of value based on "fair price": that goods and services (including labor and capital) will be traded at competitive prices. If individuals pay more or receive less than that competitive price due to market power, two kinds of mjustice have occurred. First, those individuals are made worse off than they would be if there were a fair exchange. Second, they have been subjected to an exercise of power by other private parties, which is itself a violation of social norms. Procedural fairness also involves ensuring that processes of exchange, such as bargaining practices, are intrinsically fair irrespective of their outcome.

Many scholars have also shown that these procedural fairness norms, as well as other social and political norms, were important in the enactment and amendment of the antitrust laws. ${ }^{9}$ Thus, one coinmentator wrote that the antitrust laws were "not only directed towards achieving coinpetitive prices for consumers, but also [towards] restructuring the economy in a way that would insure a 'fair' process for, and context in which, our economic, social, and political decisions would be made." 10 These social and political concerns may have even been of parainount importance: "The fact that the relatively efficient trusts at times raised prices, in an era when prices ... were on the average stable or falling, may have caused less public anger than that caused by the trusts' social and political power."11

Thus, it can be seen that market power creates the potential for violating social, political, and economic norns other than economic efficiency. The antitrust laws were enacted in large part to respond to these other concerns. Furtherinore, in no subsequent governmental discussion of the inodification or extension of the antitrust laws has economic efficiency ever been propounded as the primary-much less the exclusive-policy objective.

It is in this sense that the Guidelines represent a radical departure from a rich and varied antitrust tradition at the Justice Departınent, in Congress, and in the courts. Based at least upon a certain degree of modesty about the limitations of economic theory and empirical

9. See, e.g., United States v. Aluminum Co. of Am. (Alcoa), 148 F.2d 416, 428-29 (2d Cir. 1945) (Hand, J.); Schwartz, "Justice" and Other Non-Economic Goals of Antitrust, 127 U. PA. L. REv. 1076 (1979) (justice and procedural fairness important purposes of antitrust laws); Pitofsky, The Political Content of Antitrust, 127 U. PA. L. Rev. 1051, 1063-65 (1979) (sponsors of antitrust legislation could not have been concerned solely with efficiency).

10. R. Lande, The Goals of the Antitrust Laws $\$ 9-60$ (unpublished manuscript) (forthcoming in 34 HASTINGS L.J.). While the quoted passage is in the section on the Sherman Act, the author makes similar points in his discussion of the Clayton and FTC Acts, and notes that "[those] acts were passed in large part to fill in the gaps in the Sherman Act's coverage . . . " Id. at 153.

11. Id. at 59. 
knowledge, and also upon the legitimacy of distributional and fairness concerns as pohicy objectives, antitrust has been an eclectic body of policies. The current Justice Department, however, appears willing to promulgate the idea that the theories of the Chicago School of Economics are not only necessary, but are also sufficient for antitrust policy. The legislative history of the antitrust laws and the body of knowledge developed im antitrust enforcement prior to 1982 seem to have been either overlooked or considered immaterial. ${ }^{12}$

\section{B. Basing Antitrust Policy on Neoclassical Models}

Neoclassical price theory is a powerful theoretical construct because it simplifies reality. Assumptions such as perfect information, costless transactions, profit-maximizing firms, and utility-maximizing consumers can be entirely appropriate in solne situations. Often, economic theory provides a useful starting point for analyzing economic probleins by helping to formulate critical insights into complex inatters. One should be wary, however, of drawing policy inferences froin models founded on assumptions that are incongruent with reality. As Professor Schmalensee has warned, "[A] sound antitrust policy cannot be founded on the fiction that the world is simple."13 The complexities of the real world make it inappropriate to base legal rights and duties that can have economic consequences in billions of dollars on the predictions of a model that is efficacious because of its lack of realisin. ${ }^{14}$

Instead, rights and duties should be based on tested economic knowledge. ${ }^{15}$ The primary use of models is to provide hypotheses, which must then be tested in the real world before they can be used for public policy or other practical applications. ${ }^{16}$ Theory alone is not

12. See also infra note 69.

13. Schmalensee, Another Look at Market Power, 95 HARv. L. REv. 1789, 1789 (1982).

14. See also infra text accompanying notes 52-54.

15. See Stigler, supra note 1 , at 9.

16. Philosophers of science have imcreasingly criticized the lack of empirical foundation for economic "laws":

Economic thcories often resemble, in their logical structure, theories in the natural sciences, but the process economists use to construct their theories is peculiar to the discipline. . . Unlike other sciences, economics-primarily but not exclusively neoclassical economics-places excessive einphasis on the development of fully formulated theoretical systems without sufficient einpirical grounding of the behavioral assumptions and antecedent conditions: economists "are virtually the only would-be scientists who are content to use stale, second-hand data collected chiefly by governunent agencies for other purposes." Thus, inost of the problems in identifying einpirical relationships, which later become necessary in the process of theory testing and policy formation, are ignored. Oftcn developed with only a judicious use of mathematics, economic theory consequently lacks empirical import and policy usefulness in comparison to theory in the natural sciences.

Swaney \& Preunus, Modern Empiricism and Quantum Leap Theorizing in Economics, 16 J. EcoN. IsSUES 713, 714 (1982) (footnote omitted). 
enough to guide antitrust enforcement. The authors of the Guidelines, however, evidently believe that reasonable people need only follow the dictates of neoclassical price theory to divime a relevant market and assess the economic consequences of a proposed merger. ${ }^{17}$ We do not accept that proposition.

II

\section{The Guidelines' Approach to MARket Definition}

The Guidelines use market definition as a means of determining market power, and thus the anticompetitive effects of a proposed merger, in a fairly typical three-step process. First, the Justice Department will define the relevant market in product and geographical terms, and will determine which firms operate within that market. If the merging firms operate in the relevant market, the merger is classified as horizontal; if in successive markets, vertical; and if in unrelated markets, conglomerate. Second, the Department will calculate the Herfindahl-Hirschinan Index (HHI), a measure of the sizes of the leading firms in that market. ${ }^{18}$ Third, the Department will consider the HHI value as well as a number of other economic factors (such as entry barriers or the industry's past performance) to determine whetler to bring suit to enjoin the merger, or to seek conditions for approval of the merger.

This Part discusses several ways which commentators have suggested to determine market power and market definition. It then details the methodology used by the Guidelines to define the relevant market. Specific criticism of the Guidelines' approach will be deferred to Part III.

\section{A. Direct Measurements of Market Power}

The reliance on market definition as an intermediate step in the

17. See also infra notes $41-46$ and accompanying text.

18. See U.S. Dep't of Justice, Merger Guidelines $\S$ III(A), 47 Fed. Reg. 28,493, 28,497 (1982), reprinted in 71 CALIF. L. REv. 649, 655-56 (1983) [hereinafter cited without cross-reference as Guidelines].

We infer that the choice of the HHI in preference to the four-firm concentration ratio is based on a behavioral assumption about the relation between the degree of competitiveness $\mathrm{m}$ an industry and the size distribution of large firms. Suppose, for example, that industries $A$ and $B$ have the same four-firm concentration ratio of $80 \%$, with ten other firms each having $2 \%$ market shares. In industry A, the largest firm has a market share of $50 \%$, and the next three largest firms each have $10 \%$. In B, each of the four largest firms have market shares of $20 \%$. The HHI for industry A would be 2840 , considerably above the Guidelines' upper threshold value of 1800 . Industry B would have the same concentration ratio, but an HHI of 1640, below the 1800 threshold. The Guidelines thus would lead to the conclusion that industry B is significantly more competitive than A, a conclusion that does not appear to be based on any empirical evidence. See also infra note 66 . 
assessment of proposed mergers is in itself an acknowledgment of the practical limitations of economic theory. Market definition ineasurements are only a means of determining market power, i.e., a firm's ability to earn supracoinpetitive profits because it can raise prices and lose few sales. It is market power that is the object of the antitrust laws, not market definition itself. Some commentators have therefore sought methods of making direct measurements of market power.

One such direct measurement of market power is the price elasticity of deinand facing the firm (own-price elasticity), or the change in the quantity a firm sells of its product $A$ given a change in the price of A. ${ }^{19}$ If the demand curve for $A$ is perfectly elastic, the firm cannot raise its price past that prevailing in the market, lest it lose all of its sales to competing firms. If the demand curve is fairly inelastic, the firm can theoretically increase profits by increasing price, ${ }^{20}$ and thus has some market power.

This approach is flawed, however. First, the price elasticity of demand facing a newly merged firm cannot be estinnated. ${ }^{21}$ Second, in order to examme factors which may relate to market power, such as potential entry by other firms, one would need to know whether the substitution effects underlying an elastic deinand curve were based on product substitution, geographic substitution, or some combination of the two. The own-price elasticity measure does not separate the two. Third, demand elasticity is not a static measure, and will depend upon the duration of tine over which it is measured. If it is measured over the short run, then the possibilities for expansion of capacity, new entry, or substitution are likely to be minimal, and the curve will be inelastic. But if it is measured over the long run, the likelihood of each will increase, as will demand elasticity. ${ }^{22}$

19. See, e.g., Landes \& Posner, Market Power in Antitrust Cases, 94 HARv. L. Rev. 937, 93963 (1981).

20. This power is only theoretical, however, because managers seldom have perfect information about the elasticity of demand, or even about their marginal costs. Therefore, they do not necessarily price at the profit maximizing level (the point at which marginal cost cquals inarginal revenue).

21. A firm's own deinand curve may be elastic (responsive to price) for one of three reasons. First, there may be an income effect: if the price of a product goes up, people will buy less of that product because they have less money to spend. This effect is typically important only when a large share of total income is spent on that product. Second, there could be supply substitution: in response to an increase in price by one firm, buyers will switch to alternative supphers of the product. The area in which they switch is the geographic market for the product. Third, there may be product substitution: buyers respond to an increase in the price of one product by buying more of other products. The products to which buyers switch are called substitutes.

22. The extraordinary obstacles facing any possible atteinpt to measure elasticities have been detailed in Landes \& Posner, Should Indirect Purchasers Have Standing to Sue Undcr the Antitrust Laws? An Economic Analysis of the Rule of lllinois Brick, 46 U. CHI. L. REv. 602, 619-21 (1979), and have been acknowledged by other commentators, see, e.g., 2 P. AREEDA \& D. TURNER, ANTItrust LaW, I 507, at 330-31 (1978); R. BoRK, The ANTITRUSt PARADox 125-27 (1978); Boyer, 
A second approach to direct measurement of market power is based on profitability. If a firm can charge prices above its marginal costs over a sufficiently long period of time, the firm is likely (although not certain) to have inarket power. Assuming that longrun marginal cost is equal to longrun average cost, pricing above competitive levels would produce excess profits. ${ }^{23}$

There are both conceptual and empirical problems with this approach, however. The conceptual flaw is that one carmot distinguish between excess profits in output markets, with which antitrust cases are generally concerned, and excess profits in input markets (e.g., from control over scarce resources or access to lower priced inputs). ${ }^{24} \mathrm{~A}$ merger would have no effect on the degree of market power exercised in the latter case.

The empirical flaw in the profitability measure is that the realworld accounting data by which profit is customarily measured (assets valued at historical cost less depreciation) is rarely equivalent to definitions used in economic theory (assets valued at theoretical current market value). Even if one could correlate "economically correct" data with actual profit data to measure the profitability of an existing firm, use of this ineasure would require the almost impossible task of estimating future profits in order to determine whether the firm can charge supracompetitive profits in the long run. This approach would be especially flawed in the case of merger policy, as an estimation of future profits would be required not only for the firm newly created by the merger, but also for every firm in the industry that might be able to earn excess profits as a result of the merger.

\section{B. Approaches to Market Definition}

Because of the severe limitations of direct ineasurements of market power, courts and commentators have accepted market definition as a practical means of determining market power. The most important approaches to market definition have been based on: (1) "effective competition"; (2) cross-price elasticity of demand; (3) comparative prices; and (4) shipments.

The 1968 Guidelimes rehed upon an approach first suggested in Brown Shoe Co. v. United States. ${ }^{25}$ The essence of the Brown Shoe approach was a hist of factors to be considered in assessing whether two

Industry Boundaries, in Economic ANalysis and ANTITRust LaW 88 (T. Calvani \& J. Siegfried eds. 1979).

23. Theoretically, excess profits can be measured by coinparing the firm's return on investment (revenues less costs, divided by net investment) to its cost of capital.

24. P. AREeDA \& D. TURNER, supra note 22, I 510, at 333-34.

25. 370 U.S. 294 (1962). 
merging firms were in "effective competition." 26 This intuitive approach was relatively unsophisticated, and was sometimes misused. It did, however, have the advantage of practicahty and consistency with commercial realities-if not witl each newly discovered economic theory.

A second approach, advocated by some neoclassical economists as the theoretical ideal, is based on the cross-price elasticity of deinand between any two products, or the change in the quantity sold of one product (B) given a change in price of another product (A). ${ }^{27}$ According to this approach, if the cross-price elasticity of dennand is high-i.e., if a change in the price of $A$ causes a significant change in the quantity sold of B-the producers of both products should be counted in the same inarket. Hicks advocated this approach because a decrease in the price of A will generally decrease the demand for $B$, especially if $B$ is highly substitutable for $A$. If $A$ and $B$ are perfect substitutes, a decrease in the price of $A$ will cause the demand for $B$ to fall to zero. ${ }^{28}$

Boyer has given a detailed argument to show why "[ $t]$ he use of cross elasticities of demand carmot be justified by the theoretical connection between economic concepts of substitutabihty and cross price effects."29 Moreover, the problem is empirical as well as theoretical. Boyer has argued that there are severe practical problems in ineasuring and interpreting cross elasticities of demand. ${ }^{30}$ The inost obvious of

26. Id. at $324,325,336$. The factors included "industry or public recognition of a subinarket [that constituted a separate inarket for antitrust purposes] as a separate economic entity, the product's peculiar cliaracteristics and uses, unique production facilities, distimct customers, distinct prices, sensitivity to price changes, and specialized vendors." Id. at 325 (footnote omitted). For other variations, see, e.g., Dougherty, Elimination of the Conduct Requirement in Government Monopolization Cases, 48 ANTITRuST L.J. 869, 882 (1979); Stein \& Brett, Market Definition and Market Power in Antitust Cases-An Empirical Primer on When, Why and How, 24 N.Y.L. ScH. L. REv. 639, 663-68 (1979).

27. A similar ineasure can be used to calculate the cross-price elasticity of demand between sales in two geographic areas.

28. J. Hicks, Value and Capital 44 (2d ed. 1946).

29. Boyer, supra note 22, at 94-95:

First, the correspoudence between the degree of substitutability and the cross elasticity of deinand is not one-to-one. Given a large enough income effect, substitutes inay display positive cross price effects, or perhaps opposite cross elasticities depending on which price and quantity are varied.

Second, goods are defined as substitutes only with reference to single points on the indifference gap. The same goods may be complements at one point aud substitutes at another.

Third, even "perfect substitutes" may lave a zero cross elasticity of demand if the prices of the two goods are not in the neighborhood of those which will cause the deinand for oue or the other to fall to zero. . . .

Fourth, the Hicksian concept of substitutability has no meaning for groups of consumers, only for individuals. Since cross elasticities are only measured for groups of buyers, it is not clear what the theoretical connection is between cross elasticities and the degree of substitution.

30. Boyer's four concerns are the inpossibility of identifying the firms in the market, the implausibility of estimating a demand curve, misspecification of the inodel (for instance, finding a 
these problems is that $\mathrm{m}$ order to measure cross-price elasticity among markets (geographic and product), one must first identify all relevant supphers, then obtam price and sales data for all of those firms. Boyer thus states, "These problems are so severe that, to my knowledge, there has never been a simgle case where actual measurements of such elasticities have been used to define the boundaries of existing markets." ${ }^{31}$

In light of these measurement problems, Areeda and Turner advocate a third approach, the use of comparative price data for defining the relevant market. ${ }^{32}$ This approach compares the change im the price of $B$ given a change in the price of $A$. The argument behind this approach is that to the extent products A and B are substitutes (or areas C and D part of the same geographic market), one should observe a pattern of similar price changes between two products or geographic areas. According to Areeda and Turner, other factors, such as buying or selling patterns over time, should be considered only if price comparisons are not possible due to lack of data, or if they lead to conflicting or ambiguous results.

While we agree that comparative price data is valuable information, we cannot agree with Areeda and Turner that it should serve as the primary basis for market definition. Often, reliable price data will not be available. When it is available, there are many factors affectimg output prices, such as factor prices or a shift in the industry demand curve, that tend to confound their apphicability in defining markets. For example, producers in New York and Los Angeles may employ labor from a national umon, contract for their equipment from national manufacturers, and purchase raw materials from the saine worldwide market. Their prices may then tend to move identically even if buyers on one coast would not consider purchasing from the producer on the other coast because of enormously high transportation costs. Even if the price data in this case were reliable, the resulting market definition would not be.

A fourth approach to defining markets can be termed the "shipments" approach. Developed primarily for the question of geographic market definition, the shipments approach suggests that the pattern of actual sales between buyers and sellers should be used to define the relevant market. ${ }^{33}$ Thus, for example, where a firm in area $D$ buys from firms in areas $\mathrm{C}$ and $\mathrm{E}$, those actual sales patterns would be used

high cross-elasticity of demand in an equation which predicts the consumption of home heating oil on the basis of its price and that of tomatoes), and the existence of two cross-elasticities of demand between two goods, which might evcn have different signs. Id. at 95-96.

31. Id at 95 .

32. P. AREedA \& D. TURNER, supra note 22, I 521.

33. Elzinga \& Hogarty, The Problem of Geographic Market Delineation in Antimerger Suits, 18 Antitrust Bull. 45 (1973). 
to determine how much of $\mathrm{C}$ and $\mathrm{E}$ would be included in a geographic market with $\mathrm{D}$. The shipments approach also recognizes that two firins may not be in the saine geographic market at one point in time, but may become part of the saine inarket a year later if, for exainple, a sluinp in local sales causes firms in area $F$ to sell to distant inarkets at the later time. Indeed, the shipments approach looks to whatever underlying factors should be considered in deciding which producers, and how much of their output or capacity, ought to be counted as part of the relevant inarket.

\section{Steps in the Guidelines' Market Definition Approach}

In a sense, the Guidelines' approach to inarket definition is a hybrid of these approaches. It begins by taking the product of the inerging firm as a beginning point to establish a provisional product inarket. ${ }^{34}$ This is consistent with the shipinents approach, but is only the Guidelines' first step.

The Guidelines then state that the Justice Departinent will determine whether buyers would respond to a $5 \%$ price increase by shifting to other products within one year. If so, it will expand the market to include those products. The process of expansion will continue until a hypothetical firm that was the only present and future seller of the products in the inarket could raise price profitably. ${ }^{35}$ In other words, the Departinent would define a provisional inarket, create an imaginary inonopohst in that inarket, and ask whether that imaginary 1nonopolist could increase its profits by increasing its price 5\%. As long as the imaginary inonopolist could not earn supracoinpetitive profits because buyers would buy substitute products, then those products would be included in a new and broader provisional market.

The hypothetical used to define the provisional inarket essentially involves the estimation of the cross-price elasticity of deinand. In order to determine whether the availability of product B would limit the profitability of a price increase by an imaginary inonopoly producer of product $A$, one inust first estimate the cross-elasticity of deinand between $A$ and $B$ in order to calculate the shift of buyers froin A to B.

34. Guidelines $\S \mathrm{II}(\mathrm{A}), 47 \mathrm{Fed}$. Reg. at 28,494, 71 CALIF. L. Rev. at 651.

35. Strictly speaking, the Guidelines require only an estimate of whether the cross-price elasticity of B with respect to A exceeds some threshold level, rather than a "point estimate" of crosselasticity. For exainple, suppose the imaginary monopolist, AA, produces 2000 units of product $A$, and that the only possible substitute for $A$ is product $B$. The Department could then estimate the loss of sales required to reduce AA's profits, given a $5 \%$ imcrease in the price of A. Assume that loss is 200 units. The hypothetical question then becomes whether a $5 \%$ mcrease in the price of A will cause a sales loss of inore than 200 units from product A to product B. That is equivalent to asking whether the cross-price elasticity between $A$ and $B$ is greater than 2.0 (as a $5 \%$ increase in the price of $\mathrm{A}$ would then cause a $10 \%$ loss of sales). 
Next, one must estimate cross-price elasticity between product $\mathrm{A}$ and any other possible substitute to $A .{ }^{36}$

Having completed that chore, the Guidelines then require a calculation of profitability after the loss of sales by the producer of $A$ to all other substitutes. Only if the hypothetical monopolist can earn supracompetitive profits by charging supracompetitive prices do the Guidelines find the provisional product market to be the relevant market. If the provisional product market is not the relevant market, the Guidelines require reiteration of the process, namely, determining once again what products are substitutes for those in the new provisional market.

Once the Departinent has defined the relevant product, it would then follow the same procedure for identifying the firms that produce, or could produce, that product. Thus, it would include firms that have "existing productive and distributive facilities that could easily and economically be used to produce and sell the relevant product within six inonths in response to a . . . price increase of five percent."37 In other words, the Guidelines define the relevant market by counting firms not currently producing the relevant product, but which could easily do so by "production substitution."

The process then turns to defining the relevant geographic market, i.e., identifying the firms that produce or could produce the relevant product at relevant locations. Again, the Department will take the location of the merging firms as a starting point to establish a provisional geographic inarket based upon the shipinent patterns of that firm and its closest competitors, then consider whether buyers would turn to alternative locations in the event of a 5\% price increase in the provisional inarket. If so, the output of those producers would be included in a new provisional market, and the process repeated until an imaginary monopolist could not increase its profits by mcreasing its price.

Thus, relevant product and geographic markets, and the producers and potential producers identified in those markets, are determined by speculating upon future responses to hypothetical future $5 \%$ price $\mathrm{m}$ creases. Once the relevant product and geographic markets are so defined, the Departinent would normally include the total sales or capacity of all firms or plants within the relevant market. ${ }^{38}$ Downward adjustments would be inade for internal consumption and the supply likely to be available from potential producers. ${ }^{39}$

36. Guidelines § 11(A), 47 Fed. Reg. at 28,494-95, 71 CALIF. L. REv. at 651 .

37. Id. \& II(B)(1), 47 Fed. Reg. at 28,495, 71 CALIF. L. REv. at 652.

38. The Department will also include the total sales or capacity of firms that recycle or recondition durable products. Id. $\S \mathrm{II}(\mathrm{B})(2), 47 \mathrm{Fed}$. Reg. at 28,495, 71 CALIF. L. REv. at 653.

39. See id. $\S \S \mathrm{II}(\mathrm{B})(1)$ n.17, $\mathrm{II}(\mathrm{B})(3)$ n.20, 47 Fed. Reg. at $28,495 \mathrm{nn} .17$ \& 20, 71 CALIF. L. 
In addition to this series of hypothetical questions, the Department will also consider any other evidence it considers relevant. The Guidelines state that the Department will give particular weight to a number of factors, most of which appear in the Brown Shoe hist and have been used by previous courts, the 1968 Guidelines, and antitrust commentators. ${ }^{40}$

III

\section{CRITIQUe OF THE GUIDELINES' MARKet Definition Process}

This Part criticizes the market definition procedures outlined in the Guidelines, primarily on the ground that they will typically produce biased estimates of the relevant market that will tend to understate the anticompetitive effects of the merger under review. It also argues that the Guidelines' procedures are flawed because they are unrealistic, both in their underlying assumptions and im the method they use to determine the relevant market.

\section{A. Institutional Characteristics}

Our first criticism of the Guidelines' market definition procedures is that they lack institutional reahsm. The Guidelines are founded on neoclassical price theory, which views buyers and sellers as rational, optimizing actors, with more or less perfect information about prices and product attributes. ${ }^{41}$ Where these conditions exist, buyers and sellers need not form any relations with each other, as buyers will simply look for the lowest price. The Guidelines thus assume that markets behave in this manner. Most econolmic transactions do not occur in such inarkets, however, so that model is of limited usefulness in antitrust. ${ }^{42}$

Though there is an enormous variety of market types, it is helpful to delineate six discrete categories:

Rev. at 652 n.17, 653 n.20 (referring to id. § II(D), 47 Fed. Reg. at 28,496, 71 CALIF. L. Rev. at 654-55).

40. Id. § II(A), (C), 47 Fed. Reg. at 28,495, 28,496, 71 CALIF. L. Rev. at 651, 654.

41. For a thorough critique of the implicit use of an auction model in neoclassical theory and its implications for public policy analysis, see A. OKUN, PRICEs AND QUANTITies 13478 (1981). Okun offers an alternative model of markets based on a recognition of buyer-seller relationships, the costs of search by buyers and customer acquisition by sellers, and "satisficing" (versus maximizing) beliavior by economic agents.

42. Precisely because auction markets work so much like the perfect competition model of classical economics, there have been no significant antitrust cases in which buyers and sellers were exchanging in an auction market. Even Chicago Bd. of Trade v. United States, 246 U.S. 231 (1918), did not involve the auction market itself, but buyer-seller relations between the members of the exclange and the commodity buyers or sellers who they represented. Thus, the market in Chicago Bd. of Trade was a "relational" market. 
1. Auction Markets: The identities of the buyer and seller are unknown to each other. A disinterested auctioneer simply matches up buy and sell orders. The terms of trade do not take account of past or future transactions.

2. Bidding Markets: These are like auction markets in some respects, but with one crucial difference-the auction is conducted by either the buyer or the seller, who is therefore not a disinterested intermediary. (Examples are oil leasing, government procurement, and large purchasing departments in manufacturing firms.)

3. Relational Markets: There is a relationship between the buyer and seller, who "meet" in person, by phone, or by mail. The terms and conditions of any single transaction are influenced by the ongomg relationship of the parties, especially by their prior or potential transactions. (Examples are retail goods and services markets.)

4. Contractual Markets: There is a contractual relationship between buyer and seller which transcends a single transaction, but that is limited to one or a few objects of exchange. (An example is a longterm supply contract between an electric utility and a coai supplier.)

5. Franchise Markets: There is a contractual relationship between buyer and seller that transcends a single transaction and covers a wide range of goods and/or services, mcluding supplies, advertismg, architectural services, financing, or management services. (A retail franchise is an example of this.)

6. Obligational Markets: There is a contractual relationship between buyer and seller spanning a period of time. The conditions of exchange include provisions that shift to the buyer the locus of control over, but not ownership of, the object exchanged. (Examples are employment contracts, which give the employer authority over the employee, and equity investment, in which the shareholder gives control over the use of capital to managers.)

This categorization of market types is important because buyers and sellers in markets typically have relationships which transcend individual exchange transactions. These relationships are founded upon convenience, reduced transaction costs, personal friendships, or merely habit. Rarely are buyers (sellers) interested solely in the lowest (highest) possible price; few real-world transactions take place in the totally impersonal setting of an auction market. The Guidelines, however, generally assume that transactions do take place in that setting. ${ }^{43}$

43. The Guidelines occasionally pay lip service to the possibility that a market will not meet these specifications. Each time, however, it is clear that the Guidelines are making an exception; the general model still assumes that buyers will respond to price fluctuations by taking all of their business to the lowest priced seller. Instead, the Guidelines should set up the likelihood that buyers will not be willing to incur all the costs involved with finding the lowest priced seller as 
Whether for public policy or managerial purposes, the definition of a narket ought to begin by identifying the imstitutional nature of the market, including sucli factors as:

1. The contractual nature of the relationship between sellers and buyers. Are sales made on a "spot" basis, or do buyers typically have long-term contracts with sellers?

2. The usual volume per transaction and frequency of transactions. Do buyers purchase small quantities often, or large quantities periodically?

3. Whether transactions involve bundling of products. Do wholesalers buy a full product line from a single supplier?

4. The stability of the relationship between buyers and sellers. Have buyers historically bought from a regular supplier, or have they changed suppliers frequently, and if so, for what reasons?

5. The stability of the market in question. Have the patterns of supply been changing over time? Is total output growing or declining? Has the number and size of firms in the industry been growing or declining?

6. The institutional relationships among buyers and sellers spanning markets. Are nost firms in the industry inultimarket firms, selling in inany geographic markets? Are there national or regional trade associations that might provide information to managers about conditions in adjacent inarkets?

7. Whether some firms in the industry provide services. In many industries, some firms sell strictly on the basis of delivermg a given tangible commodity on the basis of low price, while others are "full service" firms (i.e., companies that provide pre- and post-sales advice, information, maintenance, or other assistance to buyers). In these industries, it may be inappropriate to define a market as including both types of firms, even though both sell the sanie goods.

It is admittedly difficult, or sometimes even impossible, to quantify soine of these factors. But as good marketing managers realize, marketing judgments inust be regularly based on no more than experience, common sense, and intuition. In the inajor texts on inarketing manageinent $^{44}$ and in our marketing inanagement experience, ${ }^{45}$ definition of

part of the main model. Neoclassical auction markets, and not markets in which buyers are "satisficing," are the exceptional cases in the real world.

44. See, e.g., S. BritT \& H. Boyd, Marketing MANAgement AND Administrative ACtion 3-17, 111-89 (1973); P. KotTer, Principles of MARKeTing 266-90 (1980); L. Stern \& A. El-ANsary, Marketing Channels 3-146 (1982); ANal ytical Approaches to Product and Marketing Planning-Proceedings of a Marketing Science Institute Confrerence 1116 (R. Srivastava \& A. Shocker eds. 1982).

45. Prior to his graduate education, Professor Harris worked in marketing positions with 
an actual market has not been determined in any manner resembling that of the Guidelines.

Antitrust policy ought to be concerned with the motives and practices of actual managers, and not with the theoretical constructs of neoclassical price theory. If managers of firm $X$ do not perceive territory $Y$ as part of their market, and have no interest in expanding into it, the fact that the drafters of the Merger Guidelines would assert that $X$ is part of the relevant geographic market does not make it part of that market. Similarly, if a buyer perceives that firm $Z$ comprises the entire market because of a mutually satisfactory long-term relationship, no lyypothetical construct will change the fact that the buyer will not search the entire imdustry for another supplier in response to a small change im price. Moreover, the judicial system of antitrust enforcement is well equipped to make such factual determinations; it is less able to mete out hypothetical justice.

The above discussion also shows, why the Guidelines' auction market assumptions lead to a bias in the direction of expanding the market. Buyers who operate in an auction market will have a inuch wider variety of possible sellers than will buyers who face high information costs in determining the lowest priced sellers or who have a satisfactory ongoing relationship with a single seller that they do not wish to disturb. ${ }^{46}$ Furthermore, the assumption of perfect information implies greater ease of entry. This could lead to defining a market that includes potential entrants whose desire to enter the market, or whose knowledge of entry conditions in the industry, is only hypothetical.

\section{B. Identifying the Provisional Market}

The initial step in the Guidelines' market definition process is the identification of "existing patterns of supply and demand" 47 in defining the provisional product and geographic narkets. While this language is consistent with that used by advocates of the "shipments" approach to market definition, there is a fundamental difference between that approacl and the Guidelines' approach. The Guidelines' definition of the provisional market will alinost surely overstate the true extent of

Time, Inc. and General Motors Corp., and founded and served as president of Young America Corp., a nationwide specialty marketing firm.

46. A. OKUN, supra note 41 , at $143-48$, shows how the hotel industry might work with an auction market, and then discusses the factors that make the auction model inappropriate in that industry-and most others.

47. Guidelines $\S \mathrm{II}(\mathrm{A}), 47 \mathrm{Fed}$. Reg. at $28,494,71$ CALIF. L. Rev. at 651 . This does not mean that the Department is basing its market definition exclusively upon existing patterns. Rather, these patterns are only used as a basis from which the Department continually expands the provisional market to reach the relevant market. 
effective competition, and subsequent steps in the Guidelines' methodology will only magnify this original error.

The central flaw in the definition of the provisional market is that the Department will normally include the total sales or capacity of all firms (or plants) previously identified as being in the market. ${ }^{48}$ This simply assumes away the question of the degree to which one can define a relevant market on the basis of existing patterns of supply. The Department's sole stated concern is that existing patterns may understate market size. They might, however, just as easily overstate the market. We can best explain this point by way of two examples, one for product definition, the second for geographic definition. While the error at each step of the process is analytically identical, the total error is the sum of two individual errors, because the error of the first step will be repeated at the second.

Suppose the inerging firms both produce widgets and sell them to readily identifiable industrial users, many of whom can readily substitute quidgets for widgets. The Guidelines would then define the provisional product market to include widgets and quidgets, and proceed from that point. ${ }^{49}$ Yet if supply relationships between the quidget producers and their nonwidget using customers would limit their output beyond current sales to widget using customers-e.g., if all quidgets were taken up by contract so that widget using customers could not substitute quidgets for widgets-then counting all of their capacity would overstate the size of the market.

Alternatively, suppose that zidgets have been defined as the relevant product market and all zidget producers have been identified, so the question is the geographic scope of the market. The merging firms are located in St. Louis and Cincinnati and sell throughout the Midwestern states, as do producers in Detroit, Cleveland, and Chicago. Except in the case of price discrimination; when the Guidelines might define a narrower geographic market, ${ }^{50}$ all of the output of firms throughout the Midwest would be counted in the market. If, as is often the case, producers have long-term supply relations and are unable to

48. The Department will also include in the provisional market the total sales or capacity of firms or plants that: (1) could shift their production to the relevant product (production substitution); (2) produce recycled or reconditioned goods that are substitutes for new products; and (3) produce the relevant product for internal use. Id. $\S \mathrm{II}(\mathrm{B}), 47 \mathrm{Fed}$. Reg. at 28,495, 71 CALIF. L. REV. at 652-53. In what the Guidelines appear to consider the exceptional case, where total sales or capacity would overstate the competitive significance of such a firm, the Department will include a smaller part of total sales or capacity. Id. $\S \mathrm{II}(\mathrm{D}), 47 \mathrm{Fed}$. Reg. at 28,496, 71 CALIF. L. REv. at $654-55$.

49. "If . . price discrimination is possible, the Department will consider defining additional, narrower relevant product markets oriented to the buyer groups subject to the exercise of market power." Id. \& II(A), 47 Fed. Reg. at 28,495, 71 CALIF. L. REv. at 652.

50. Id. § II(C), 47 Fed. Reg. at 28,496, 71 CALIF. L. Rev. at 654. 
shift their sales readily (or any other of the myriad sources of "friction" markets exist to prevent equilibration to price changes), then countimg all of the output of the Chicago, Detroit, and Cleveland firms may overstate the competition they represent for the merging Cincinnati and St. Louis companies.

Thus, we emphasize that the Guidelines are replete with possibilities for expanding the provisional inarket, but are generally unconcerned about constrictimg it. Therefore, it is likely that the final market definition will be too wide, and that as a result, many inergers which result in anticoinpetitive harms will not be prevented. Moreover, the total bias induced by counting the total output of all firms im the provisional market is additive if the error is made at both steps in the process.

\section{The Hypothetical Monopolist and the "5\%" Rule}

But the Guidelines do not stop at provisional markets. Once the market has been provisionally defined, the Department will then look for producers not found to be part of the provisional market but which should be counted in the relevant market. In order to execute this step, the Department einploys a hypothetical question: whether an imaginary monopolist would be able profitably to raise price by $5 \%$ (as a first approximation). ${ }^{51}$ If not, the market has been defined too narrowly. Our second and third criticisms of the Guidelines' inarket definition process relate to the use and effects of this hypothetical.

As a first objection, this construct is simply impracticable. It would require an enormous number of calculations of cross-price elasticities between any given provisional product or geographic market definition and all possible additions to it. There will virtually never be adequate data to make such calculations, and we doubt that the Department has the resources to make the calculations if the data were available.

Second, the use of a hypothetical monopolist as a means of measuring the market is simply devoid of any commercial reality. The Department states that it will assume that buyers and sellers will immediately recognize the liypothetical $5 \%$ price increase. ${ }^{52}$ This means that the Departinent is not simply considering a lypothetical monopolist, but hypothetical competitors as well. No manager, however, has imstantaneous, costless information about conditions in adjacent markets; it is difficult enough to expect managers to be able to understand conditions im their own markets, given the cost and fre-

51. Id. § II(A), 47 Fed. Reg. at $28,495,71$ CALIF. L. Rev. at 651 .

52. Id. n.10, 47 Fed. Reg. at 28,495 n.10, 71 CALIF. L. Rev. at 651 n.10. 
quent unavailability of information. ${ }^{53}$ Furthermore, the hypothetical monopolist is not about to announce its price increase to its hypothetical coinpetitors in order to determine the limits to its market power.

Some of the best evidence about the lack of information about anticompetitive pricing behavior can be obtained from the Department of Justice itself. In a recent survey of seventy-five price fixing cases brought by the Department over the period 1961-1970, ${ }^{54}$ all of which the Department won at trial or settled by plea of nolo contendere, the average duration of the conspiracy was seven years. If information about supracompetitive prices is so readily available, one wonders why it took the Department so long to discover the violations. One also wonders why potential coinpetitors did not quickly inove into the inarkets, as seven years is in inost cases long enough to build the necessary new capacity or to substitute existing production capacity to the relevant product.

Third, there is a serious technical problen with the inethod for implementing the hypothetical. The Guidelines are concerned with the behavior of competitors, given a firm's $5 \%$ increase in price. This, however, is an improper measure of a firm's inarket power. The proper imdicator of this is profitability, which is ineasured correctly as a return on investinent (ROI), not as a percentage of sales. In the high-voluine grocery business, for example, net income typically represents $0.5 \%$ of sales, so a 5\% increase in price would represent a $1000 \%$ increase im profit (stated as ROI). Surely, a sizeable nuunber of competitors not now in the inarket would enter if profits were running at that exorbitant level. Just as surely, the managers of any recently merged grocery firm would know better than to try to raise prices by 5\% across the board.

Alternatively, the hypothetical $5 \%$ increase inay understate inarket power for the opposite reason, that a larger price imcrease may be profitable for the imaginary inonopolist even if a $5 \%$ mcrease is not profitable. For exainple, suppose a inonopohst in the provisional market, Northern California, has customers only in Santa Barbara and San Francisco. Suppose also that this inonopohist perceives that a 5\% price increase would cause a substantial loss of sales because custoners in Santa Barbara would turn to Los Angeles-based supphers. In that event, the Guidelines would mclude the total output of Los Angeles firms in the relevant inarket.

53. If managers could be so well informed about the product or geographic markets adjacent to those in which they currently operate, we would expect that sources such as trade association reports would report that fact and some of the evidence. We are not aware that this is a common practice, however.

54. Hay \& Kelley, An Empirical Survey of Price Fixing Conspiracies, 17 J.L. \& EcoN. 13, $17-$ 28 (1974). 
But suppose that the same Northern California monopolist could raise price an additional $10 \%$ with no further loss of sales to Southern California competitors due to the transportation costs involved. In that event, the Guidelines would have overstated the true size of the market for the San Francisco customers who would not buy from Los Angeles suppliers even when the monopolist charges these supracompetitive prices. The relevant question is not whether a given price increase (5\%) results in supracompetitive profits, but whether any price increase does so. In the above situation, the Guidelines' $5 \%$ hypothetical does not expose the market power of the inonopolist.

This problem arises when there is a small but significant group of buyers at the fringe of a market who can readily turn to other suppliers, while most buyers at the core of the market have no such choice. The deniand curve is kinked in these situations; it is more elastic at some prices, and inore inelastic at others. Apparently, the Guidelines assume that all deniand curves are monotonic and of more or less uniforn elasticity.

The saine criticism can be made with respect to product market definition in the Guidelines. If the Department wants to use a hypothetical inonopolist as the conceptual construct for defining the market, the relevant question is whether there is any price increase that would be profitable for the monopolist, not whether a particular price increase would be profitable. If soine fringe buyers can readily turn to other products (high elasticity of substitutability), but others cannot (low elasticity), the Guidelines may once again reach the wrong conclusion.

In order to avoid this problem, the Guidelines might have chosen to pose the hypothetical in the correct forn and ask wliether any price increase would still be profitable for the monopolist. The problein with posing the hypothetical in the correct forn is that the measurement and proof difficulties-serious enough with the 5\% rules-are greatly exacerbated. Because the hypothetical construct leads to a choice between a strong possibility of incorrect results and intractable problems of proof, we believe that the hypothetical concept itself is of little value in an adversarial process.

Fourth, the hypothetical 5\% increase is an attempt to measure whether a seller can profitably raise prices, which requires deternining the extent to which buyers will substitute other products, given the price increase. This is therefore an implicit measure of cross-price elasticity of demand, but one which is used by the Guidelines without a specification of the price from which the hypothetical $5 \%$ increase will occur. ${ }^{55}$ Because it is generally true that the cross-price elasticity in-

55. See, e.g., Landes \& Posner, supra note 19, at 960-61. See also infra note 59. 
creases with price, and that price is in turn a function of the existing degree of market power, the Guidelines' inethodology will overstate the relevant market whenever firms already possess sufficient inarket power to raise price above coinpetitive levels.

Suppose, for exainple, that the coinpetitive price of cellophane is $\$ 1.00$ per unit, and the competitive price of waxed paper is $\$ 0.50$. At those prices, waxed paper inay not be seen as a good substitute for cellophane. But if the producers of cellophane had the inarket power to raise the price to $\$ 2.00$, waxed paper nnay be seen as a good substitute. Thus, if the Guidelines' 5\% rule were applied to a $\$ 2.00$ base price, inany buyers might shift to waxed paper, so that a hypothetical monopolist would not increase its profit at the higher price. If the rule were applied to a $\$ 1.00$ base price, few would shift, and the inonopolist would be exercising market power.

The correct base price is the coinpetitive level, $\$ 1.00$, as inarket definition is a ineans of ineasuring inarket power-e.g., whetlier the monopolist could charge supracompetitive prices. But the Guidelines' methodology might lead to measuring cross-price elasticity from a base price $(\$ 2.00)$ that is already supracompetitive. The conclusion might then be wrongly drawn that the relevant product market is "flexible wrapping inaterials." 56 In short, the problem is that because the liypothetical 5\% mcrease (cross-price elasticity of dennand) is higher as a result of a firm's market power, it is a poor way of measuring the extent to which a firm exercises inarket power.

Fimally, it does not add to the hypothetical's value that the Guidelines suggest that various other factors can also be taken into consideration. ${ }^{57}$ One does not correct a fundamental mistake by heaping additional inforination on it; one starts witl a method that is conceptually sound and leads to determinable results. Furtlierinore, the Guidelines offer no clues whatever as to how those additional factors will be measured, how they will be weighted, or how conflicts between any two imdicators will be resolved.

\section{Behavioral Assumptions of Intermarket Mobility}

Even if it can be assumed that potential entrants liave perfect market information, these potential entrants should be defined within the inarket only if they might actually enter the inarket. One set of barriers to market mobility is that firms have relations with existmg custoiners, whether they imvolve contracts that fix legal riglits and duties, or whether they are just longstanding business relationships. Marketing

56. The Supreme Court made this error in United States v. E.I. du Pont de Nemours \& Co. (Cellophane), 351 U.S. 377, 399-400 (1956). See also infra note 59.

57. See supra note $\mathbf{4 0}$ and accompanying text. 
managers and sales personnel have a real stake in mamtaining the loyalty of current customers, and typically seek additional outlets or market opportunities when they can expand sales without jeopardizing their existing customer base. In Okun's terms, there is a cost of acquiring a customer, and therefore a corresponding opportunity cost of losing a custoiner; inost firms are willing to mcur that cost only if there is soine longer term benefit froin selling elsewhere. ${ }^{58}$

But even if the potential coinpetitor can switch some of its sales, adjust production, or expand its output if a profitable opportunity arises im an adjacent product or geographic market, it is not necessarily safe to assume that it will do so. That decision will depend upon the cost-and risk to individual managers-of entering the market. If there is some significant fixed cost, such as in establishing new sales offices or developing the necessary transportation or warehouse facilities, then a reasonable manager would want to determine the likelihood of long-term success. If the opportunity is due to the inarket power of the current incunibent-the Department hypothetical monopolist or a real one-and the entry of this or similar firms would have the effect of reducing price to the normal coinpetitive level, then the sunk costs of entering the market are likely to make entry unprofitable.

\section{E. Predictability and Certainty}

The inethodology of the Guidelines is not a set of standards that can be applied with certainty. If one asked two different market analysts to define a given market, relying on whatever information thought necessary but following the Guidelines' inarket definition process, two reasonable people could come to dramatically different results. The Guidelines contain exceptions and escape hatches, and Antitrust Division officials who wanted to escape the Guidelines' simplistic approach and overly broad market definitions would have little trouble justifying their actions by the wording of the Guidelines. ${ }^{59}$

As the matter presently stands, however, that is unlikely to occur, at least as the Antitrust Division is now constituted. There is every

58. See, e.g., A. OKUN, supra note 41 , at 143.

59. Baxter is himself apparently willing to ignore the Guidelines when their application would reach inappropriate results. Thus, he stated that although applying the Guidelines in the Cellophane case would lead to the wroug result, "[i]n any context in which hypothesizing a higher price is the right approach, the market definition approach described in the Guidelines would be what [the Justice Department] would follow. Where that's not the right question, obviously we won't follow that." Hills, Baxter, Campbell \& Turner, Panel Discussion: The New Merger Guidelines, 51 ANTITRust L.J. 317, 332 (1982) (response by William F. Baxter, Jr., at ABA Antitrust Section Meeting, Aug. 11, 1982). To the best of our knowledge, however, he has not yet set forth criteria for determining when the Guidelines should be ignored.

This type of approach can also lead to the type of uncertainty that the Guidelines were ineant to avoid. See infra note 69. 
reason to believe that the same principles of neoclassical price theory and minimization of commercial realities that were important in the drafting of the Guidelines would also be used in their implementation. Thus, while there inay still remain a degree of uncertainty as to how the market might be defined in a given merger, it is highly probable that the Antitrust Division will implement the Guidelines with a bias in the direction of the broadest possible market definition.

\section{F. Market Expansion}

Our final criticism of the Guidelines' market definition is related not to any particular step im the process, but to the whole of the process. We readily acknowledge that defining markets is a very difficult task, that even under the best circumstances serious ineasurement problems remaim, and that reasonable pcople with the best intentions will come to different conclusions about what constitutes a relevant market. In recognition of the inherent difficulty, we would not treat as fundamental any criticism we might have on any one particular issue. There is, however, a more overriding consideration involved here.

At every one of the major steps and at most of the subsidiary ones, the Guidelines use procedures which have the effect of increasing the size of the market, and therefore of reducing the shares of the merging firms in the market. Although in some cases the Guidelines' methods may produce unbiased results, it is uniformly true that whenever there is the possibility of bias, it is always in the same direction of market expansion.

We cannot beheve that this result is accidental. Nor can we believe that it is merely the result of applying a particular version of neoclassical price theory to the question of market definition. The Guidelines are, first and foremost, a statement of the political position of the present Justice Department. That fact is important in assessing the implications of the Guidelines for merger enforcement, and for antitrust enforcement more generally. We address these concerns in Part IV.

\section{IV}

IMPLICATIONS FOR MERGER POLICY Y AND ANTITRUST ENFORCEMENT

We believe that the Guidelines' market definition methodology is likely to have strong adverse effects upon merger enforcement. But we also believe that the methodology could adversely affect any nonmerger areas of antitrust enforcement in which market definition is im- 
portant. $^{60}$ In this Part, we consider the implications of the Guidelines' market definition process as it might be applied by the Department in deciding whether to enjoin a merger, in litigation against merging firms, in nonmerger antitrust enforcennent, and in the Department's intervention in private litigation of antitrust violations. We also consider the likelihood of private parties using the Guidelines' market definition process in antitrust litigation, and the effects such use would have.

\section{A. Effects on Merger Prosecution}

\section{Specific Types of Mergers}

The Guidelines' market definition process and its tendency to define markets broadly will almost certainly decrease the number of Justice Departinent challenges to horizontal mergers. A larger market reduces the market shares of an industry's firms, lowering the HHI of the industry and decreasing the likelihood that a given merger will be challenged by the Justice Department. The enforcement posture of the Department is an important factor for firm managers to consider in reaching merger decisions. Thus, once nnanagers recognize that the rules of the game have changed, they are likely to attempt inergers they might not once have even considered, whether in the belief that the mergers will not be contested, or in the search for the outer boundaries of the new Guidelines.

The market definition process is unlikely to affect vertical inerger enforcement because the Guidelines have so greatly circumscribed vertical merger enforcement of any kind. ${ }^{61}$ Accordingly, even if the Guidelines' market definition process were biased toward showing a "vertical relationship" between inerging firms-an issue on which we express no opinion-1narket definition would probably not have inuch effect on the nuinber of vertical merger challenges.

As with vertical mergers, the Guidelines appear to signal an end to the enforcement of conglomerate inerger activity. In this area, however, the market definition process inay have the ironic effect of increasing the number of Justice Department challenges. Products or areas that might ordinarily be seen as unrelated may be included in the same market because of the Guidelimes' tendency to result in overly broad market definitions. Therefore, mergers that inight otlerwise have been considered conglomerate may be classified as horizontal by the Guidelines' approach. Because the Guidelines express the view

60. For a list of antitrust violations requiring market definition and citations to representative cases, see, e.g., Jorde, The Seventh Amendment Right to Jury Trial of Antitrust Issues, 69 CALIF. L. REv. 1 (1981).

61. See, eg., Ordover \& Willig, The 1982 Department of Justice Merger Guidelines: An Economic Assessment, 71 CALIF. L. REv. 535, 567-68 (1983). 
that "non-horizontal mergers are less likely than horizontal mergers to create competitive problems," 62 it follows that the Guidelines' broad market definition process could result in more challenges to these "reclassified" conglomerate mergers than would occur with a narrower process.

This appears to have happened in United States $v$. Virginia $\mathrm{Na}$ tional Bankshares, Inc. ${ }^{63}$ a suit brought by the Department under section 7 of the Clayton Act to enjom a merger of two banks in Wise County, Virginia. To support its position that the merger was horizontal and not conglomerate, the government presented expert witnesses who used the hypothetical market definition approach to claim that the relevant market was the entire county. Local bankers, on the other hand, unanimously agreed that the relevant markets were much narrower, centering around small towns within the county. The court did not accept the government's overly broad hypothetical market definition, and refused the government's request for an imjunction. ${ }^{64}$

\section{Increase of Anticompetitive Harms}

The inain effect of the Guidelines, however, will be to increase the likelihood that the Department will err in the direction of too little antitrust enforcement, thus increasing the anticompetitive hanns suffered by society. It may be impossible to design a system of antitrust enforceinent such that all inergers with anticompetitive effects, and only those with anticompetitive effects, will be prosecuted. The American legal process, however, has ways of minimizing damage when the system errs toward too much antitrust enforcement. No such minimization is possible when the error is in the other direction.

In any system of evaluating legal alternatives, two types of error are always possible. A type I error is wrongful enforcement-for example, an innocent person being found guilty-while a type II error is wrongful nonenforcement-for exainple, a guilty person being found innocent. It is typically true that the probabilities of the two errors are

62. Guidelines $\S \mathrm{IV}, 47$ Fed. Reg. at $28,499,71$ CALIF. L. Rev. at 660 .

63. 1982-2 Trade Cas. (CCH) \64,871 (W.D. Va. 1982) (oral bench opinion).

64.

[W] hen we consider the fact that what the government has here is speculative based on what might happen as distinguished from the real world which has been testified by the bankers in this case who are down at the grass roots and know what's going on, that this Court will be utterly foolish to go off chasing rainbows, and the government has not borne the burden of proof.

Id. at 72,353 .

If judges are generally averse to accepting inarket definitions based on hypothetical methods, the end result of using the Guidelines' approach will be even less successful antitrust enforcement. Fewer merger challenges will be made than before, and many of the challenges that are brought under the preseut Guidelines will be dooned to failure because the government will be unable to prove a relevant market. 
inversely related, so that taking steps to reduce a type I error, such as imposing a very high standard of proof in criminal cases, will simultaneously increase the probability of a type II error. Even if legislative bodies search for rules that minimize both types of errors, there will always remain soine irreducible probability of error. The problem then becoines how to choose between errors of the two types. ${ }^{65}$

The answer to that question depends upon the consequences of the two types of error. For exainple, the reason we impose very high burdens of proof in the criminal law is that our society places an extraordinarily high value on personal freedoun. We find the idea of imprisoning an innocent person offensive to our values. Therefore, in the process of protecting against wrongful imprisonment (type I error), we accept the fact that inore guilty persons will be let free (type II error).

An agency unust also confront this dilemma in setting standards for the enforceinent of inerger laws. If the standards for allowing mergers to remain unchallenged were too stringent (type I error), so that the Justice Department challenged soine mergers that did not actually violate the antitrust laws, there would be some small possibility that a inerger would be wrongfully enjoined and that resources would be unnecessarily used in prosecuting and defending against the suit. But the consequences of that possibility are minimized in our systein of justice because a full hearing must be held before an injunction is issued. If, on the other hand, the standards for prosecuting inergers were too high (type II error), and truly anticompetitive inergers were not challenged, there would be no further opportunity for the courts to correct the error of nonprosecution.

The Guidelines are likely to maximize socially harmful type II errors in merger enforceinent. The inethodology of the Guidelines creates an overly broad nieasure of inarket definition, which in turn may produce a ineaningless $\mathrm{HHI}$ below the minimum threshold for inerger challenges. ${ }^{66}$ Where this occurs, it ensures that a inerger that is actually

65. For a discussion of these error types in statistical inference, see, e.g., W. MENDENHALL, Introduction to Probability aNd Statistics 132-38 (3d ed. 1971).

66. The use of the HHI might seem at first glance to mject an element of precision into the measure of the size distribution of firms. There is little difference in a mathematical sense between the HHI and the four-firm concentration ratio, see, e.g., F. SCHERER, INDUSTRIAL MARKET Structure ANd Economic Performance 58 (2d ed. 1980), and the $\mathrm{HHl}$ is a numerical measure which is easy to work with and to make coinparisons froin.

The problein is that the value of the $\mathrm{HHI}$, and thus whether the Guidelines' threshold levels are exceeded, critically depends upon the definition of the relevant market. The more broadly the market is defined, the lower the $\mathrm{HHI}$ (or the concentration ratio) will be. Thus, regardless of which measure of size distribution is used, defining the relevant market in the inanner stated in the Guidelines will greatly understate the anticompetitive effects of many mergers. Neither the $\mathrm{HHl}$ 
anticompetitive will be consummated. Society then suffers the very harms that the antitrust laws were imtended to prevent.

\section{B. Effects on Merger Litigation}

Even though the Guidelines state that they are "designed primarily to indicate when the Department is likely to challenge mergers, not how it will conduct the litigation of cases that it decides to bring,"67 we believe it highly improbable that the government will ever approach market definition any differently than the methods suggested by the Guidelines. ${ }^{68}$ To do so would detract from the Guidelines' evident goal of reducing uncertainty in the business commumity. ${ }^{69}$ The Virginia National Bankshares case is a good example of the Department usmg an approacli to market definition im merger litigation that bears a striking resemblance to the approacl of the Guidelines. But that case also demonstrates that a highly theoretical, hypothetical approach to market definition is useless when carried into a courtroom.

There is a fundamental difference between the practice of econom-

nor the four-firm concentration ratio can be a precise measure of anything if the market definition methodology leads inevitably to maccurate determinations of size distribution.

67. Guidelines § I, 47 Fed. Reg. at 28,494, 71 CALIF. L. Rev. at 649.

68. U.S. Dep't of Justice, Explanation and Summary of the Merger Guidelines, reprinted in Trade Reg. Rep. (CCH) No. 546, at 55 (June 16, 1982) (special supplement to 2 Trade Reg. REP. (CCH) I 4225 (Aug. 9, 1982)).

69. "By stating its policy as simply and clearly as possible, the Department hopes to reduce the uncertamty associated with enforcement of the antitrust laws in this area." Guidelines \& I, 47 Fed. Reg. at 28,493, 71 CALIF. L. Rev. at 649. See also William French Smith, Introduction to Merger Guidelines, reprinted in TRADE REG. REP. No. 546, at 5 (June 16, 1982) (special supplement to 2 Trade Reg. Reg. (CCH) I 4225 (Aug. 9, 1982)); Baxter, A Justice Department Perspeciive, 51 AnTrTrust L.J. 287, 288 (1982) (speech to ABA Antitrust Section, Aug. 11, 1982).

One possible effect of these Guidelines, however, will be to increase uncertainty in the business community. The Guidelines are a statement of policy of the Justice Department of the current Administration. They are also a clear brcak with the logical evolution of antitrust law that was occurring before this Administration took office. See supra notes 6-12 and accompanying text. This dramatic shift in antitrust policy invites later administrations to promulgate enforcement policies radically different froin those of their immediate predecessors, resulting in antitrust policies that may be stable only until the next presidential election. Business decisions that are significant enough to lave potential antitrust effects, however, are made for the long run, and cannot be undone every four years.

This undesirable effect can be avoided if future administrations base their enforcement policies on the whole of the antitrust law existing at a given time, and not simply on one set of untested theories. Antitrust law would thus be better served if the 1982 Guidelines were treated as an aberrational shift in merger policy. While the likelihood of this cannot be predicted at this time, it appears that even commentators favorable to the Guidelines are not sure of their longterm effects:

The new guidelines on market definition represent ... a great advance in economic sophistication over the 1968 guidelines. Drafted under the close supervision of President Reagan's Antitrust Division Chief, William Baxter, they represent in fact the triumph, short-lived though it may prove to be, of the economic approacl to antitrust law in the thinking of enforcement officials.

R. POSNER \& F. EASTERbraOK, AitTitrust 33 (Supp. 1982-83) (emphasis added). 
ics by academicians and the practical evidentiary requirements necessary in a court of law. As Judge Williams made abundantly clear in Virginia National Bankshares, market definition by economic experts, no matter how consistent it is with economic theory, is not adequate for judicial purposes if it is uninformed by prevailing commercial realities. Thus, we fully expect that if the Department does use the Guidelines' approach to market definition im litigation, it will continue to confront profound evidentiary and proof problems stemming from the speculative nature of the hypothetical inquiry.

The market definition methodology of the Guidelines will also have an effect upon private litigation over merger activity. Because inerger challenges typically are taken before economic damages occur-i.e., before the firm resulting from the merger can exercise the market power allegedly gained by the merger-private parties have traditionally not played an important role in the enforcement of merger policy. The major exception has been the use of antitrust claims by target companies to provide the legal basis for enjoining unwanted takeovers. To the extent that the Guidelines lend credibility to a broadly defined market, we expect the incidence and success rate of takeover defenses based upon antitrust claims to increase, because the bias in market definition will work in favor of finding a horizontal relationship between the target and acquiring firms.

\section{Effects on Nonmerger Litigation}

Because the Guidelines were a high priority of Assistant Attorney General Baxter and were the product of inore than a year's work by Department economists and lawyers, ${ }^{70}$ it is reasonable to assume that the market definition provisions will be applied in the Department's exercise of prosecutorial discretion in other cases that require an assessment of market power. We would expect the Department to tend toward nonintervention in these noninerger areas, as is likely in the merger area. Thus, smgle-minded adherence to neoclassical price theory and its unrealistic assumptions is likely to result in reduced antitrust enforcement in general, not just in the field of mergers.

The Department's current enshrinement of allocative efficiency as the sole goal of antitrust and sole determinant of the Department's enforcement efforts represents an arrogation of power in the executive branch, at the expense of Congress and the courts. This "activist" role of nonenforcement is particularly troublesome because it cannot be easily checked by the other branches of government. ${ }^{71}$ Were the De-

70. E.g., Smith, supra note 69 , at 5 .

71. There is a notable inconsistency between the Reagan administration's avowed antagonisin to judicial activism and the atternpts of the Justice Department to overturn conventional 
partment erring on the side of excessive enforcement of the antitrust laws, the courts would stand ready to take corrective action by deciding cases in favor of defendants. Such corrective steps cannot be taken, however, if the Department simply refuses to enforce the antitrust laws, thereby vitiating thein. To be sure, Congress could enact special legislation directing specific enforcement and providing specific funds for the task, but such action is an exceedingly crude enforceinent tool, and should in any event be wholly unnecessary in a properly functioning deinocracy.

The attitude and ideology of the Justice Department thus raise serious questions about the future of government enforcement of the antitrust laws. But there is a potential for even greater inisehief because of the Departinent's threat to carry its neoclassical mission directly into private litigation by seeking to intervene in private antitrust cases. Baxter has publicly stated that the Department may well intervene on the issue of 1narket definition in private antitrust actions, including nonmerger cases. ${ }^{72}$ It is certainly ironic that the government is willing to spend its resources ni private cases, when one reason for the Guidelines was undoubtedly to indicate where the government would choose to spend scarce prosecutorial resources. ${ }^{73}$ But more importantly, the possibility of imtervention threatens to bring into the courtroom all of the probleins associated with the Guidelines' approach to market definition.

Finally, even in the absence of government imtervention in private antitrust litigation, we can safely assume that defendants will press upon the courts the inarket definition methodology set forth im the Guidelines, as they are the usual beneficiaries of broader inarket definition. And quite apart from the pro-defense biases in the Guidelines,

legal doctrines by promulgating standards or exercising prosecutorial discretion which result in not enforcing the laws, by withdrawing suits filed by previous Attomeys General, or by intervening in private suits to obtaim "favorable" precedents. The administration has offered no explanation as to why courts should not "make the law," but executive agencies should be allowed to do so.

72. Hills, Baxter, Campbell \& Tumer, supra note 59, at 329 (response of William F. Baxter, Jr.). If this was once a threat, it is now a promisc that has been kept. See, e.g., Brief for the United States as Amicus Curiae, McDonald v. Johnson \& Johnson, No. 82-1594-MN (8th Cir. brief filed Aug. 9, 1982) (citing to Merger Guidehines to explain various concepts of antitrust law, including unarket power). For exaunples of Department intervention generally, see Brief for the United States of America as Amicus Curiae, Paschall v. Kansas City Star Co., 695 F.2d 322 (8th Cir. 1982); Brief of the United States of America as Amicus Curiae on Rehearing En Banc, Battle v. Lubrizol Corp., 673 F.2d 984 (8th Cir. 1982); Memorandum for the United States as Amicus Curiae, Shop \& Save Food Mkts., Ine. v. Pneumo Corp., 683 F.2d 27 (2d Cir. 1982). All of the above government interventions were on behalf of the defendants.

73. See, e.g., Kauper, The 1982 Horizontal Merger Guidelines: Of Collusion, Efficiency, and Failure, 71 CALIF. L. REv. 497, 502 (1983); Schwartz, New Merger Guidelines-Guide to Governmental Discretion and Private Counseling or Propaganda for Revision of the Antitrust Laws?, 71 CALIF. L. Rev. 575, 577 (1983). 
the list of factors that will "also be considered"74 - without any guidance on how they ought to be measured or weighted-will give defense attorneys too much opportunity to delay and confuse the real issues.

When such mevitable efforts are made to move the market definition methodology into the courtroom, courts must be careful to recognize that the Department's theory-laden, hypothetical approach to market definition is not appropriate to the hitigation process. Not only are practical proof problems ignored in the Guidelines, but there is also no recognition of a court's need to reach decisions and achieve finality in a case, within the limits and constraints of an adversarial system of litigation. A more practical, litigation-oriented approach to market definition is possible, however. We will outline this approach in Part V.

$\mathrm{V}$

\section{An Alternative Approach to Market Definition}

It is not possible, within the confines of this Symposium, to set forth im full the approach that we advocate for defining markets im antitrust litigation. We will fully develop our ideas in a forthcoming issue of the California Law Review..$^{75}$ However, a number of important points can be highlightcd here in order to contrast our approach with that taken by the Department of Justice in the Guidelines.

First, market definition in the context of antitrust litigation should not be approached as an abstract economic inquiry. The antitrust laws are principally concerned with protecting the interests of buyers and sellers in a free enterprise econoniy. To protect those interests fully, market definition should begin from the perspective of the injured, or potentially injured, groups that the antitrust laws were intended to protect.

When litigation is brought by private plaintiffs, the injured parties are readily identifiable. The question then becomes whether the plaintiffs represent an economically significant group of buyers or sellers that the antitrust laws sought to protect from anticompetitive harm. When the plaintiff is the government representing the public, an effort should still be made to identify the particular interests that the government is seeking to protect in the litigation.

This "protected interest" identification will change the market defmition process from abstraction to reality, and will provide a beginning point for defining the relevant market or markets at issue. For exam-

74. See supra text accompanying note 57 .

75. R. Harris \& T. Jorde, supra note 4. 
ple, once the different buyers are identified who might be potentially harmed by a proposed horizontal merger, a first approximation of the relevant market should be established by determining the product and geographic space in which such buyers readily turn to satisfy their demands. Furthermore, because the process starts by identifying the interests at stake, this approach incorporates at the outset the standards of liability of the statutory provision under which the litigation is brought.

Second, the definition of inarkets takes place within a court system and within the context of an adversary relationship between the parties. This has important consequences for the proper definition of the relevant market. The evidence of market boundaries must be susceptible of proof at trial; speculation and hypothetical argument will not suffice. Moreover, the placement of the evidentiary burdens of production and persuasion regarding inarket definition can be critical. A useful approach to market definition would specifically address each of these points.

Once a plaintiff has identified the product and geographic space in which it normally trades, we would permit the plaintiff to calculate market shares and industry concentration ratios on the basis of a total market universe based on actual sales of the relevant product in the relevant geographic area. Although additional sources of the relevant product may be available from other product producers or from other geographic areas, proof of such potential sources of supply would not be required as part of plaintiff's primia facie case.

We recognize that potential sources of additional supply may be available in a dynamic market setting, and that such sources might have an effect upon a defendant's ability to exercise market power to control price or output. Similarly, potential imcreases im production, capacity, or new entry, or potential diversion of supply from other products, unarkets, or internal consumption may, under certain circumstances, exercise some degree of control over a defendant's short-run inarket power. But because such potential sources of supply are by nature considerably more speculative than actual sales in the relevant market, and because an mdustry defendant has more access to imdustry sources of information, we believe it appropriate to shift to the defendant the burden of production respecting these issues. We would not permit the defendant to meet its burden with speculation or hypothetical argument about what might happen in the future. Hard evidence, based upon past inarket practices or upon testimiony from experts imtimately familiar with the history and practices of the mdustry, would be required.

Third, information about markets and transactions is often poor, 
and data in these areas often conflict. Therefore, a sound approach to market definition inust identify quite specifically the factors that ought to be considered in the market definition process, how each of those factors can best be measured and the effects of alternative measures on the process, and how the factors ought to be weighted in deciding the market definition issue. Courts-as well as public enforcement officials and agencies-must necessarily rely on heuristics, or rules of thumb, to guide examination of complex issues.

Fourth, market definition must be based on economic knowledge, not economic theory. Theory is useful if it is consistent with the observable world. But when we must choose between the convenient assumptions of neoclassical economics and constructs based on the probable behavior of buyers and sellers in their economic relationships, we should surely choose the latter over the former.

By economic knowledge, we do not mean merely the kind pubhished in academic journals and government reports. While it is surely too nuch to make the neoclassical assumption that economic actors have perfect information, there is an enormous repository of economic knowledge in the minds of corporate managers, sales personnel, purchasing agents, and others actively involved in commerce and industry. The best person to ask whether a particular firm is likely to enter a given inarket, for example, is not an independent economist relying on statistical data, but soineone who has experience in the market. The appropriate role of professional economists is not to make judgments based on their knowledge of economic theory, but to ask the right people the right questions, and to make a "whole" market definition out of the niany parts.

While our approach is directed primarily to courts and hitigants engaged in antitrust market definition, it also offers an excellent perspective for the exercise of prosecutorial discretion. When the Justice Department evaluates a merger or any other potential antitrust violation to determine whether a complaint should be filed, it may find it prudent to ascertain the existence of potential sources of additional supply and the effects that such sources might have upon market power. By so doing, it may better understand the nature of the transaction and the quantity and quality of the potential supply evidence that defendants might seek to introduce in rebuttal. If it appears froin investigation of readily available evidence that potential supply sources do exist that would directly affect market power, then the Department may wish to assess its case and exercise its discretion from that perspective.

The unavailability at the investigatory stage of evidence concerning potential sources of supply should not, however, preclude the possi- 
bility of the Department filing a complamt based upon the buyer's perception of the relevant market. The defendants will have an opportunity to offer rebuttal evidence concerning potential sources of additional supply, which the governinent may then surrebut. In the end, it will be up to the trier of fact to determine the boundaries of the relevant market.

We believe that this protected-imterest-oriented, burden-shiftimg approach to market definition is faithful to the purposes of the antitrust laws. If the factors used in determining markets, their measurement, and their weighting are articulated explicitly, it is also workable in a court of law. The approach values the contribution that economic theory may be able to make; but more importantly, it is founded on the market realities that buyers and sellers actually face. Finally, this approach makes the governinent an active participant in enforcing the antitrust laws, and thus in ensuring competitive markets for the benefit of consumers and entrepreneurs. 